\title{
THE
}

\section{UNESCO, URI, and Archaeology in the Deep Blue Sea: Archaeological Ethics and Archaeological Oceanography}

\author{
William H. Krieger \\ University of Rhode Island, krieger@uri.edu \\ Bridget Buxton \\ University of Rhode Island, babuxton@uri.edu
}

Follow this and additional works at: https://digitalcommons.uri.edu/phl_facpubs

Terms of Use

All rights reserved under copyright.

\section{Citation/Publisher Attribution}

Krieger, W.H. \& Buxton, B. J Mari Arch (2012) 7: 271. https://doi.org/10.1007/s11457-012-9092-y

Available at: https://doi.org/10.1007/s11457-012-9092-y

This Article is brought to you for free and open access by the Philosophy at DigitalCommons@URI. It has been accepted for inclusion in Philosophy Faculty Publications by an authorized administrator of DigitalCommons@URI. For more information, please contact digitalcommons-group@uri.edu. 


\section{UNESCO, URI, and Archaeology in the Deep Blue Sea: Archaeological Ethics and Archaeological Oceanography}




\author{
Authors: \\ William H. Krieger: Department of Philosophy, The University of Rhode Island, Kingston, RI, \\ U.S.A. \\ Bridget Buxton: Department of History, The University of Rhode Island, Kingston, RI, U.S.A. \\ Please send correspondence to William Krieger. \\ Email: krieger@mail.uri.edu \\ Phone: 4014642180 \\ Address: URI Department of Philosophy. Kingston, RI 02881
}

\begin{abstract}
Multiple groups have interests that intersect within the new field of deep submergence (beyond the 50 meter range of SCUBA) archaeology. These groups' differing priorities present challenges for interdisciplinary collaboration, particularly as there are no established guidelines for best practices in such scenarios. Associating the term 'archaeology' with projects directed at underwater cultural heritage that are QRWguided by archaeologists poses a real risk to that heritage. Recognizing that the relevant professional organizations, local laws, and conventions currently have little ability to protect pieces of cultural heritage across disciplines and international boundaries, the authors propose institution-specific mechanisms, called Archaeology Review Boards (ARBs), guided by local and international laws and conventions concerning cultural heritage, as the best means to provide oversight for academically centered archaeological activities at the local level.
\end{abstract}

\title{
Keywords
}

Archaeology. Ethics. 2001 UNESCO convention. Underwater cultural heritage 


\section{Exploration of the deep}

We are fortunate to live in an age when scientific and technological innovation has resulted in the creation of a variety of vehicles (both human driven and remotely operated) that have extended our reach into the deepest waters. As a result, there have already been a number of situations, both intentional and unintentional, where using these vehicles has resulted in the discovery of underwater cultural heritage, and some oceanographic expeditions are indeed now setting out with the precise purpose of discovering shipwrecks, underwritten by federal funding for ocean exploration. ${ }^{1}$ The creators and operators of these craft are ocean scientists and engineers located in industry and in the oceanographic research community, and in addition to developing the vehicles used for deep-water survey and exploration, they generally subsidize deep-water archaeological work substantially or exclusively through their own financial means. In fact, one of the highest premiums is on space on research vessels. Costs average $\$ 30,000$ 40,000 per day for the use of an appropriately equipped oceanographic research vessel, which is well beyond the financial capabilities of most professional archaeologists (Ballard 2008); in the commercial realm the cost of a work-class ROV vessel and its crew begins at $\$ 50,000$ per day

${ }^{1}$ A few recent examples of these partnerships include the National Oceanographic Partnership Program 2010 study of the mid Atlantic http://www.nopp.org/2010/nopp-sponsors-deep-waterhard-bottom-habitat-study/ (accessed December 21, 2011); Robert Ballard's 1997 exploration of the Black Sea for the purpose of finding ancient dwellings inundated when this freshwater body was flooded by rising sea levels approximately 7150 years ago. http://www.geo.edu.ro/sgr/mod/downloads/PDF/Ballard-MarGeo-2000-170-253.pdf (accessed December 21, 2011); NOAA's 2008 mission to discover historic shipwrecks off Turks and Caicos islands http://www.research.noaa.gov/spotlite/ (accessed December 21, 2011); the PHAEDRA project, 2006 http://oceanexplorer.noaa.gov/explorations/06greece/background/archaeology/archaeology.html (accessed December 21, 2011); and the many projects of the Wood's Hole Oceanographic Institute, including http://oceanexplorer.noaa.gov/explorations/06greece/background/archaeology/archaeology.html (accessed December 21, 2011). 
(Søreide 2011); in some cases, depending on the complexity of the job, commercial boats with work class ROVs can average up to $\$ 250,000$ per day.

Some other groups interested in deep-sea industry, such as the oil and gas sector, now adhere to federally mandated protocols under The Bureau of Ocean Energy Management (BOEM) whose jurisdiction covers all federal submerged lands, including the continental shelf, slope, and basin up to 200 nautical miles. ${ }^{2}$ Businesses engaged in deep-water activities are required, under certain conditions, to employ archaeologists and adhere to BOEM's guidelines where cultural heritage is concerned. In these commercial contexts, work cannot proceed without the guidance of a professionally qualified archaeologist. This expert contributes to the expedition planning process from the beginning, and must be physically present to direct, observe, and report on all diving investigations. BOEM provides oversight of this process as the reviewing agency for all results produced, and has published guidelines establishing everything from the correct format of archaeological reports to the recommended height for towing sides-can sonar fish in a variety of survey scenarios. ${ }^{3}$ The regulatory environment for the U.S. oil and gas industry with respect to archaeological heritage is still evolving, but since 1966 the Minerals Management Service has been responsible for protecting archaeological resources on the Outer Continental Shelf, and industry has proven itself as a genuine stakeholder in the preservation of deep-sea cultural heritage. The existence of positive legal requirements has even resulted in partnerships between the industry and professional archaeologists. Excavations such as the Mardi Gras (Ford 2010)

\footnotetext{
${ }^{2}$ http://www.boem.gov/Regulations/BOEM-Governing-Statutes.aspx (accessed March 27, 2012).

${ }^{3} \mathrm{http} / / /$ www.boem.gov/Regulations/Notices-To-Lessees/2005/05-G07.aspx; see also the survey guidelines in http://www.gomr.boemre.gov/homepg/regulate/regs/ntls/2005\%20NTLs/NTL2005G07.pdf (accessed March 27, 2012).
} 
show the potential for research collaboration beyond the basic commercial relationships that already exist between the oil and gas industry and the CRM archaeological community.

However, in this new age of deep-water exploration outside of the jurisdiction of organizations such as BOEM, the legal waters are still mostly uncharted (O'Keefe 1999). As a result, academic institutions are lagging behind management agencies such as BOEM in establishing guidelines for deep-water research activities that impact cultural heritage, especially when the research takes place outside U.S. jurisdiction. In the absence of effective legal safeguards or even well established models for best practices in many parts of the globe, a university-sponsored research expedition that is either partly or entirely 'archaeological' in purpose (for example, finding shipwrecks) can proceed without the same level of archaeological oversight that would be mandated on an equivalent terrestrial project. In addition to the questions of oversight, such an expedition can easily operate without awareness or respect for archaeological procedures or priorities, or understanding of current international or local agreements on the proper care of underwater cultural heritage. In the United States, there is currently nothing that parallels the BOEM regulations concerning the appropriate behavior of U.S.-based ocean scientists conducting deep-water survey in areas of high archaeological potential, and the United Nations Convention on the Law of the Sea (UNCLOS) and other applicable international laws do little to clarify the situation.

What then of more informal standards and regulations, of the kind established through long practice and publication within the terrestrial archaeological community? Following in the footsteps of other field changing texts, such as Maritime Archaeology (Muckelroy 1978) and Shipwreck Anthropology (Gould 1983), the most comprehensive statement outlining an oceanographic view of the nature, potential, and appropriate practices of deep submergence 
archaeology from the perspective of the United States is Archaeological Oceanography (Ballard 2008), which showcases the achievements of twenty years of Institute for Exploration (IFE) expeditions. ${ }^{4}$ This vision for deep-water archaeology captures the sense of almost unlimited potential for discovery that the deep oceans represent. The technology of deep-sea exploration is indeed awe-inspiring to the outsider, and the pioneering and innovative spirit that inspired the first major American deep submergence archaeology (DSA) projects deserves admiration.

Despite the introduction of this new archaeological-oceanographic platform, it appears that no one has yet stepped forward to ask the difficult but necessary questions this new disciplinary and operational paradigm raises from the perspective of archaeologists. At the same time, from the oceanographic perspective, there is a very real concern that the archaeological community cannot understand the needs and perspective of oceanography as an academic discipline.

Communication and understanding are at the key issues here, complicated by the fact that both oceanographers and archaeologists employ research terms (such as 'survey' or 'sample') that have subtle but sometimes profoundly different implications within each discipline. That is why it is not enough for archaeologists and oceanographers to simply hope for the best. There must be mechanisms for ongoing dialogue and oversight. The stakes are high: if archaeologists and oceanographers cannot learn to collaborate effectively within an agreed framework of guidelines and responsibilities for the advancement of human knowledge, commercial treasure hunters will move in to fill the vacuum, assuming technological and popular leadership in the field of deep

\footnotetext{
${ }^{4}$ Although partnerships between archaeologists and ocean scientists vary from country to country, the authors of this paper contend that the issues raised here, from the perspective of the United States, do carry over to these other locales. The universal nature of this problem is, in fact, one reason that the proposed ARB (see below) has as one of its charges the evaluation of extra-URI projects for credit toward a URI degree.
} 
sea archaeological survey and excavation. Indeed, judging by popular television and news coverage of these groups, one could argue that the treasure hunters already hold this position.

\section{Where are the archaeologists?}

As deep-water exploration that impacts evidence of past human culture and activity is going to continue, and as water covers approximately $70 \%$ of the earth's surface, it is fair to ask what role archaeologists will actually play in the field. This is especially important, as archaeologists are not able to simply go to many sites: the 'field' is increasingly a place that can only be reached using the most sophisticated and expensive equipment. In the race for archaeological information, the owners and operators of this equipment are far ahead of the archaeological community in the development of tools and strategies to locate and excavate deep-water shipwrecks (Wachsmann 2011). Since the objectives of for-profit salvage operations are, for the most part, in conflict with those of professional archaeologists, professional archaeologists have determined that colleagues in the marine sciences would be the logical partners and allies for DSA. But the difficulty in this partnership is setting our appropriate ground rules so that oceanographers and archaeologists do not need to feel that their tools and expertise are essentially being subordinated to the research goals of their partners' discipline.

Here, Archaeological Oceanography's answer seems a very appropriate one. To quote from the introduction: "The term 'archaeological oceanography' sounds like the former is subordinated to the latter but this is not the case. A geological oceanographer is a geologist working in the ocean. An archaeological oceanographer is an archaeologist working in the ocean as well." (Ballard $2008, \mathrm{x}$ ). This begs the question of whether the term 'oceanography' is needed at all to describe practitioners of this new sub-discipline, when archaeologists regularly collaborate with scientists in other realms without needing to redefine themselves or their activities. Indeed, Søreide has 
observed that "in reality there are no oceanographic archaeologists... there is archaeology that occurs in deep water but it is simply archaeology" (Søreide 2011, 7). The question here revolves around what it means to be an archaeologist.

That said, Archaeological Oceanography's definition of itself would seem to align perfectly with the recently-ratified UNESCO 2001 Convention on the Protection of the Underwater Cultural Heritage (CPUCH), Annex rule 22: "Activities directed at underwater cultural heritage shall only be undertaken under the direction and control of, and in the regular presence of, a qualified underwater archaeologist." ${ }^{5}$ Although several important maritime nations, including the United States of America, have not signed the $\mathrm{CPUCH}$, many archaeological groups and research institutions have formally or informally endorsed its core principles. ${ }^{6}$ In fact, one of the significant differences between $\mathrm{CPUCH}$ and its annex is: "The Convention represents a compromise text, as any multilateral treaty, between various views and perspectives. However, the annex of the Convention was a unanimously adopted text. Its technical rather than legal (and/or political) nature helped in achieving such a result (remarkable in a genuinely multilateral negotiation)." (Carducci 2005, 1) This unanimous support in committee has been reflected in the reception to the two documents in the larger world. While a number of countries (for a variety of reasons) are reluctant to sign $\mathrm{CPUCH}$, many governments and groups worldwide look to the annex for support. An example of this spreading wave of archaeological agreement on the annex

\footnotetext{
${ }^{5}$ For the text of the 2001 UNESCO Convention on the Protection of the Underwater Cultural Heritage, see: www.unesco.org/new/en/unesco/themes/underwater-cultural-heritage/the-2001convention/. A closely related document, and inspiration for many of the provisions in the CPUCH annex, is the ICOMOS Charter on the Protection and Management of Underwater Cultural Heritage: www.international.icomos.org/under_e.htm (accessed December 21, 2011). ${ }^{6}$ See for example the website of the Advisory Council for Underwater Archaeology (http://www.acuaonline.org), which contains links to the CPUCH and ICOMOS documents, and summarizes the objectives of the CPUCH as part of the official ACUA underwater archaeology ethics press kit.
} 
was a two-part international workshop and conference on this topic, which resulted in a report (Greene 2010) and a statement of guidelines for best practices, based on the annex and endorsed by a group of archaeologists working in maritime contexts. Other groups and institutions in the United States, such as the Institute of Nautical Archaeology, ${ }^{7}$ the American Institute for Conservation of Historic and Artistic Works, ${ }^{8}$ the Archaeological Institute of America, ${ }^{9}$ and the University of Rhode Island Archaeology Group ${ }^{10}$ have adopted the annex's guidelines as well. Among the safeguards archaeologists take for granted with terrestrial sites (or underwater sites within the state waters of a sovereign nation, or in areas designated as significant in federally controlled waters) is the requirement that there be archaeological oversight of projects that have the potential to discover or disrupt $\mathrm{UCH} .{ }^{11}$ As a part of this process, the archaeologist's qualifications, experience, and research plan is reviewed before the survey or excavation is approved, and a suitably trained archaeologist provides oversight. In the case of projects undertaken by the oil and gas industries, although the government does not send its own archaeologists on each survey, any archaeologist (Principle Investigator) that is contracted to oversee these projects has to meet the U.S. Secretary of the Interior's requirements for a professional marine archaeologist and prepare a report that is sent to the BOEM archaeologists for review. As deep submergence research activities often occur in international waters, archaeologists are concerned that there is no outside authority forcing the project leaders to

\footnotetext{
${ }^{7} \mathrm{http} / / /$ inadiscover.com/about/ocomos_charter (accessed December 21, 2011).

${ }^{8} \mathrm{http}: / / \mathrm{www}$.conservators-converse.org/2011/08/aic-releases-statement-on-the-10th-anniversaryof-the-adoption-of-the-unesco-convention-on-the-protection-of-the-underwater-cultural-heritage/ (accessed December 21, 2011).

${ }^{9} \mathrm{http} / / / \mathrm{www}$. archaeological.org/news/advocacy/93 (accessed December 21, 2011).

${ }^{10} \mathrm{http} / / / \mathrm{www} . u r i . e d u /$ archaeology/ (accessed December 21, 2011).

${ }^{11}$ This significance requirement is being reassessed by governmental agencies (such as BOEM) as not providing enough protection to areas that have no such designation. See below for more on BOEM's past and current practices on this issue.
} 
explain their goals or document their findings in an academically approved fashion. In fact, U.S. projects designed for the discovery of UCH in deep-water (projects that would clearly be considered archaeological in terrestrial contexts or in territorial waters) have already occurred without adequate provision for archaeological oversight or appropriate support for the study and publication of the project results. As there are no agreed upon guidelines for oversight of UCH related projects outside of U.S. jurisdiction, there is no real means for major funding agencies, or other non-archaeological groups, to conduct an effective review process for such projects. It does not help archaeologists' case that they have, as a field, allowed themselves to be perceived inaccurately in the media (somewhere between Indiana Jones and a beachcomber with a metal detector), which has led the public to assume that the role of the archaeologist is essentially to 'find' things, and therefore to assume that anyone who is good a finding things should be identified as an archaeologist, or at least empowered to act as one. Recent television shows, including Spike TV's American Digger and National Geographic Channel's Diggers, which glorify the recovery and sale of artifacts, solidify the public's perception that archaeology and treasure hunting are one and the same. ${ }^{12}$

The answer to the question "where are the archaeologists?" on an expedition directed at the discovery or disturbance of underwater cultural heritage should never be ambiguous. By unanimous agreement of the international archaeological community, and in line with best practices in terrestrial archaeology, a suitably qualified archaeologist must be fully involved and physically present for all activities that impact cultural heritage.

\footnotetext{
${ }^{12}$ Articles such as one by the Museum of Underwater Archaeology's Ben Ford highlight this problem specifically for underwater archaeologists: http://www.uri.edu/artsci/his/mua/project_journals/bf/bf_6-13.shtml (accessed march 27, 2012).
} 


\section{When is archaeology not archaeology?}

A possible response to arguments calling for archaeologists to be more involved in expedition planning and to be present on research vessels to provide oversight might be to claim that not all deep sea survey is directed towards the recovery of underwater cultural heritage. If a deep-sea voyage is planned solely for the purpose of exploration, and if these voyages are aimed at discovering (but not excavating) $\mathrm{UCH}$, they might argue, that titles aside, these projects are not archaeological. The question is whether ocean exploration directed at finding shipwrecks (as opposed to mounting an archaeological excavation of those sites) should be subject to the UNESCO Annex rule 22 (thereby requiring archaeological collaboration). Although the arguer would be correct in one sense, that exploration is not the same as excavation, the reader should not be led to the further conclusion that these activities are not bound by the annex. In fact, the word 'excavate' is not a part of Annex rule 22: “Activities directed at underwater cultural heritage shall only be undertaken under the direction and control of, and in the regular presence of, a qualified underwater archaeologist." If the annex is to guide procedure, then, at least to the archaeological community, oceanographic survey directed towards the discovery of UCH must be considered archaeology according to the terms of the $\mathrm{CPUCH}$.

Obviously, archaeologists are not capable of (and are not at all interested in) policing all deepsea voyages. The point of the discussion above (and the argument for the creation of ARBs below) is twofold. First, the authors want ocean scientists to understand why archaeologists feel a responsibility to be involved in UCH projects. Second, the authors want other stakeholders in ocean exploration to understand why a particular community - a group of professional, and here, specifically academic archaeologists (regardless of their particular academic posting) - feels a 
need to control projects that are being used to represent archaeology, due to the impact those projects can have on the sponsoring university, its students, and its faculty.

In the case of BOEM, these issues were originally addressed by designating certain areas under their purview to be potentially of high archaeological significance, based on predictive modeling from survey data collected in 1977, 1989, and 2003. Commercial operations requiring a permit from BOEM must work with archaeologists to survey those areas first, and identify and if necessary mitigate any damage to cultural material. According to this view, an oceanographic expedition off established sea-lanes in the middle of the Atlantic or Pacific would not expect to encounter significant cultural material; an expedition exploring the territorial waters of any Mediterranean country would almost certainly encounter it. In other words, it is less the title or stated purpose of the expedition that is important for determining the appropriate role of archaeology and archaeologists, but more the area in which the exploration or work is taking place.

There are problems with this geographical model for determining the archaeological significance of a region (as forward thinking as it was when it was created). Although there may be large concentrations of $\mathrm{UCH}$ in areas so designated (coastal areas, areas of known traffic, etc.), this approach, one that makes decisions based on geography and not intent, makes little theoretical sense and overlooks potential unknown areas of deposition. In addition to making it difficult to study materials that are outside of these designated safe havens, this practice would have the effect of skewing the archaeological record to reflect whatever biases caused certain areas to be protected (to the expense of others). If only certain areas are protected, and if artifacts therefore only come from those areas, any conclusions reached based on those materials will be skewed to match the initial assumptions of the group creating the areas of high archaeological significance. 
The fact is that, given new technologies and theoretical models of sea trade, areas that have in the past been considered of low importance could become critical in the future. Establishing exactly when and how an archaeologist should be involved in any particular scenario is something best done in consultation on a case-by-case basis. In fact, as early as 2004 there were criticisms of the assumptions behind the aforementioned surveys, and as of March 2011, BOEM changed their policies, now requiring archaeological assessment for all areas of the Gulf of Mexico subject to seafloor disturbance by any activity under their authority. ${ }^{13}$

. Despite claims to the contrary, the greatest source of damage to UCH comes from activities that have nothing to do with the primary goal of collecting UCH. As documented by Foley (2007), the greatest danger to archaeological heritage in the ocean is modern industrial activity, and the deployment of cables, nets, etc. that destroy underwater sites. As damage to UCH by industrial use is unintentional, there would be a real benefit to having archaeologists 'on call' to provide information and to work on problems on behalf of other groups whose work impacts on UCH. Missions focused on exploration, at times, have an impact on $\mathrm{UCH}$, and given the archaeological contention that activities that are directed toward the discovery of UCH (survey) or the disturbance or reclamation of $\mathrm{UCH}$ (excavation) are, to an extent, archaeological activities, archaeologists definitely take the view that exploration undertaken for the primary or even secondary purpose of discovering (but not excavating) UCH should be considered archaeological survey, and subject to archaeological (in addition to oceanographic) rules and standards.

In 2009-2010 the idea that the CPUCH annex should be seen as a guide to best archaeological practices was the subject of an international two-part workshop on UCH issues. Mentioned

${ }^{13}$ http://www.boem.gov/Environmental-Stewardship/Archaeology/Gulf-of-MexicoArchaeological-Information.aspx accessed March 27, 2012). 
above, "The Penn-Brock statement of principles and best practices for underwater archaeology and the stewardship of underwater cultural heritage in the Mediterranean" (Green 2010) is a document that explores the definitions of $\mathrm{UCH}$, the role of archaeologists in protecting $\mathrm{UCH}$, and the responsibility of archaeologists to work with other scientists and specialists to further their understanding of and protection of UCH. ${ }^{14}$ Our challenge lies both in working out best practices from an archaeological point of view, and in helping researchers outside our discipline understand the situation from our perspective, as well as trying to be sensitive to our scientific and engineering colleagues' different foci of attention, theoretical models, and areas of expertise.

The issues and questions outlined above are of particular concern to academic institutions supporting interdisciplinary research and teaching initiatives that involve cultural heritage, both in the ocean and in terrestrial contexts, and the evidence is clear that universities, once apprised of the issues, can and do change long-held policies in favor of compliance with archaeological ethical standards. ${ }^{15}$ Based in part on the issues above, as well as on more global concerns about the potential for abuses of projects being referred to as 'archaeology' at academic institutions across the country, the members of the University of Rhode Island archaeology group (consisting of 3 North American / Atlantic archaeologists and 3 Classical / Bronze Age / Near Eastern archaeologists) decided to explore ways in which the core principles of the preeminent cultural heritage conventions might be applied in practice at an institutional level.

\footnotetext{
${ }^{14}$ The conference report is available as a pdf file, downloadable from http://www.archaeological.org/fieldnotes/reports/3291 (accessed December 21, 2011). ${ }^{15}$ Recent examples of universities changing policies in this manner include Yale University's 2010 decision to repatriate Incan artifacts brought to Yale in 1911 by Professor Hiram Bingham III by the end of 2012 and Wesleyan University's 2010 decision to repatriate artifacts that belonged to a variety of indigenous groups in violation of NAGPRA. In this case, the push for compliance (and supervision of its implementation) was largely a result of action by a 'local level' group comprised of professors and students from Wesleyan.
} 

the level of our government and legal system did not justify the same approach at an institutional level. Academic archaeologists at universities throughout the United States of America should proactively determine the role that archaeology will play at their campuses, and at all universitysponsored projects on land and in the water. By doing this at the institutional level, a university's archaeologists could make sure that archaeological projects created at that university would be of the highest caliber, that their students would participate in scientifically and ethically rigorous projects around the world, and that the university as an institution would be associated with archaeology's best practices. The need for URI's archaeologists to form a distinctive organization in order to establish themselves as an authoritative voice for their discipline was partly because the faculty themselves were spread across multiple academic departments, which is a common situation in U.S. universities. However, even in cases where archaeological activities are concentrated in a single department, the fact that other stakeholders interested in ancient culture or artifacts exist at a university would provide good reason to create such an organization.

As representatives of the academic archaeological community, URI's archaeologists have neither the desire nor the ability to control projects by non-URI groups or by non-archaeologists. The point of URI's proposed Archaeological Review Board (ARB), and of any ARB would be to ensure that university-based archaeological projects live up to the international standards outlined above, and that students participating in outside projects would have real assurances that they were being steered toward the best the field has to offer. It is our intention that this model would serve as test case for other university faculties in archaeology who are attempting to set an example in matters surrounding archaeological best practices.

\section{Implementation at URI: Adopting ethical guidelines and identifying competent authorities}


Given the various stakeholders interested in $\mathrm{UCH}$ at the University of Rhode Island, the challenge for our proposed ARB model will be to draw up a set of guidelines and procedures that interpret the general recommendations of the relevant cultural heritage conventions within the specific context of research, teaching, and supervision conducted under URI auspices, with special attention paid to the strengths, needs, and limitations of our multidisciplinary partners.

A group invested in protecting UCH at the University of Rhode Island has decided to use the CPUCH annex's guidelines, along with other sets of policies and procedures created by respected archaeological organizations and conventions, to outline a proposed set of consistent and appropriate best practices for all archaeological research conducted by or for URI. The CPUCH holds a prominent place in this effort because deep-water archaeology and interdisciplinary initiatives with oceanography and marine affairs are a focus of URI's institutional and faculty driven research interests. Rather than invoking the $2001 \mathrm{CPUCH}$ annex and related documents as position papers, this inter-field group is looking at ways of transforming the recommendations into actual procedures endorsed and applied by our University for all activities directed at cultural heritage (on land and underwater).

The first step was to use the $\mathrm{CPUCH}$ to determine how decisions should made in regards to $\mathrm{UCH}$ policies. The convention states that these decisions are to be made by 'competent authorities'.

The CPUCH describes this in article 22.1:

In order to ensure the proper implementation of this Convention, States Parties shall establish competent authorities or reinforce the existing ones where appropriate, with the aim of providing for the establishment, maintenance and updating of an inventory of underwater cultural heritage, the effective protection, conservation, presentation and management of underwater cultural heritage, as well as research and education. 
In the attached CPUCH Annex, rules 2, 9, 11, 12, 22, and 34 explain the roles that these competent authorities play on all aspects surrounding the care of underwater cultural heritage, including the provision that archaeologists must be physically on hand in positions of authority on expeditions directed at underwater cultural heritage.

Who are these competent authorities? The CPUCH was designed to address states, but as laid out in Varmer et al (2010) the United States has not signed the convention (arguing that it could be used as a means to undermine national security on a couple of levels), there are no proactive 'competent authorities' at a national level. Since university faculty are hardly in a position to assume the power and responsibilities envisioned for government agencies, the question is: who would the competent authorities be, and how would their abilities allow them to both know international ethical guidelines and to create university policies for the protection of $\mathrm{UCH}$ ?

To answer that question, it is necessary to search for regional or national organizations that could undertake this effort. In fact, there are a number of competent national and regional archaeological organizations that already exist in the United States (e.g. the Archaeological Institute of America, the Society for Historical Archaeology, the Society for American Archaeology, the American Schools of Oriental Research), as well as non-profit consultant groups that specialize in these issues, such as the Advisory Council on Underwater Archaeology and Register of Professional Archaeologists. Each group has a code of conduct, which is at least recommended, if not binding on all members of those organizations. However, many who now participate in the study of cultural heritage are not members of those organizations and may be unwilling to defer to them as competent authorities where cultural heritage is concerned, and none of these organizations are able to perform the specific tasks outlined in the CPUCH. 
Additionally, even if regional or national authorities on $\mathrm{UCH}$ could be found, there would be questions as to their local authority (an issue that will be addressed below).

In addition to the contention that top-down legislation or structure does not provide the practical ethical safeguards that are needed at an institutional level, there are good philosophical arguments to not put too much stake in the efficacy of institutions nominally adopting general principles in lieu of local regulatory structures. This critical view of top-down legislation is far more in keeping with the philosophy of archaeology itself as a discipline. Twenty-first century archaeologists operate within a framework of international laws, conventions, and wellestablished traditions, but archaeology is just awakening to the idea that these conventions must work in concert with (and not in lieu of) good local decision-making. Project-specific approaches were not always considered ideal in a field that is in some ways still struggling to define itself between the realms of science, history, and belief. As documented in Krieger (2006), terrestrial archaeology in particular has suffered from 'law envy,' spending the middle of the twentieth century courting philosophical authorities on science to ground archaeology in a more scientific framework. This attempt, which resulted in processual, or "new archaeology" (especially the new archaeology of North America) did help to push the field forward, but this motion, instead of unifying the field, caused it to fracture into its currently dis-unified state, one where processual, post-processual, interpretive, and other global and local archaeologies make competing claims about the interpretation of (and the content of) archaeological data. ${ }^{16}$ Many of the arguments against the processual approach were directly related to the belief that this model

\footnotetext{
${ }^{16}$ Krieger (2011) argues that this is not a position to be feared. Despite the almost universal belief that scientists can only work from within a unified field (and despite the obvious counterexample, physics), archaeology has survived (and thrived) in a state of epistemological and methodological disunity.
} 
was created by an intellectual elite and applied in a colonialist manner, without regard to either epistemological fitness or local concerns, and some current archaeologists have made great strides to counteract this attitude, opening their digs to a variety of perspectives and stakeholders. Perhaps the best known of these archaeologists and excavations (in terrestrialist circles) is Ian Hodder at Çatalhöyük, but archaeologists worldwide are now making connections with indigenous groups, non-dominant communities, and others who have been ignored by past interpretations of the archaeological record.

The archaeological community is not the only group that has shown a growing distrust of trickledown governance. In the business world, this model is increasingly being seen both as an impediment to creativity (a reaction to this is the open-source movement in computer software and the Internet neutrality movement), and as an ineffective way to control behavior (despite the work of early psychologists such as BF Skinner $(1948,1984)$. Ethicist Mollie Painter-Morland believes that people should not depend on ethical guidelines coming down (by example or by fiat) from the top, instead arguing for a more integrated approach to set a businesses' moral compass:

That high-level individuals can and do play an important role in articulating priorities and shaping the sensibilities of employees within organizations is not to be disputed. However, if the role of such individuals is not to be denied, it is also not to be overestimated. An analysis of business organizations as complex adaptive systems suggests that the ineffable sense of normative congruence that develops among those who participate in an organizational system over time may be of a far more complex and relational nature. (Painter-Morland, 1980, 509)

In her article, Painter-Morland demonstrates a variety of problems that result in relying on the "great man theory," instead arguing for what she calls "systemic leadership." This approach argues that direction should (and must) come from all levels, including the ground level of an 
organization. "The emphasis that is placed on interdependency, integration, and adaptation in recent leadership literature suggests that the role and responsibilities that have typically been attributed exclusively to those who were formally appointed to positions of authority within an organization should be reconceived in more systemic terms." (Painter-Morland, M., 2008, 519) Painter-Morland's systemic leadership approach (and other similar positions) addresses problems with authoritarian business models in much the same way that archaeologists have addressed top-down archaeological approaches, and the resulting system allows for decision-making to come from all levels of the corporate structure. This model, she argues, results in better decision making, greater flexibility, the possibility for real discussion of dissent, and a sense of trust that decisions are well reasoned (a sense that is often absent when rules have been handed down without explanation from the executive boardroom, or national authority). Given these views, in an arena where absolutist directives might be regarded with suspicion or hostility especially in cross-disciplinary conversations, an integrated approach, one that utilizes global agreements, coupled with more local (here institutional) involvement and direction, seems to be the most appropriate, and equitable means to achieve the goals of documents such the $\mathrm{CPUCH}$ annex. In fact, an example of a successful institutional model already exists for implementing a review process for faculty and student activities directed at cultural heritage. For many years, the program committee for the Institute of Nautical Archaeology in the U.S.A. has monitored good archaeological practice admirably for projects under INA auspices. Since the program committee draws on the expertise of nautical archaeology faculty at Texas A\&M University, it is wellpositioned to evaluate projects both on their archaeological merits and their suitability for involvement by Texas A\&M students, as well as serve as an ongoing resource for the management of INA-sponsored projects right through to final publication. INA's example, as a 
local review board, can be seen as an ARB 'proof of concept. Local authorities, qualified to speak on archaeological matters and empowered by the guiding principles of the $\mathrm{CPUCH}$ and its annex, the Penn-Brock statement, and relevant conventions and laws already in force in the United States and in foreign countries are the best candidates to create approval and oversight processes for underwater projects impacting cultural heritage.

\section{Rationale for an ARB}

Although there is no national standard for such a review board (although the authors of this paper hope that their efforts will prove helpful for others working on the same issues) there is strong precedent for such a review board at any university. There are a number of groups on any research university campus that are held to high standards, both professional and ethical. In order to make certain that these groups work with the highest degree of integrity, universities and professional groups have created 'review boards' for each of these disciplines. An Archaeology Review Board would study and approve projects in the same way that any University with a marine science program has a diving safety office and control board, and any social science program has a committee that reviews research proposals involving human subjects, or any biology program has an animal care division and protocols for using animal subjects.

An ARB would thereby assume the role (in principle, if not in a legally binding sense) of the 'competent authority' designated by the $\mathrm{CPUCH}$. A central committee of UCH-centered faculty members would be the best (in fact, the only) group that would meet the standard of 'competency' from both an academic perspective and from any university's institutional perspective (an important distinction, which will be addressed in the next section of this paper). In terms of the academy, any university (with a faculty and/or program in archaeology) has hired a group that is charged specifically to teach its students, to present research in its name, and to 
represent the university in archaeological matters before the international community. URI is fortunate to have, in addition, a number of other faculty members who focus on cultural heritage from different academic perspectives (such as people interested in ancient textiles, a variety of earth and ocean scientists, classicists, and ethicists). These individuals and departments, inasmuch as their disciplines and interests focus on cultural heritage, need to be represented on the ARB. Rather than swell the board, URI's proposal (as of now) would be to have a standing core committee representing archaeology (and other core disciplines that are concerned with the protection of cultural heritage) with an additional list of on-call members, representing other disciplines, including oceanographers and other underwater scientists for projects in the water, textile or faunal specialists for land projects, etc. These specialists would rotate in to the group to evaluate projects that connect with their fields of expertise. In terms of institutional qualifications, this is the only body that is able to set policy (i.e. to determine whether an outside project meets the ethical, theoretical, and methodological standards to be allowed for credit toward a URI degree). Any other group of people, regardless of their personal or professional credentials, would not have this ability, and as such, could only be called upon in an advisory capacity.

\section{The ARB's Contribution to Archaeology}

Given the fact that local features will have a significant impact on archaeological practices, a campus-based ARB would spend the majority of its time addressing local problems, depending on the expertise, needs, and types of projects being pursued at that particular university, with occasional questions arising on regional, national, or international problems. Whether these larger issues could be handled 'in house' or in consultation with other scholars (or other ARBs, either privately or at conferences), by keeping focus on the institution, the ARB would be the 
means to ensure proper oversight for all archaeological projects, whether they take place on land, in territorial waters, or in areas that are outside the normal organizations and territories where strict cultural heritage laws and ethical guidelines are already enforced. An ARB would endeavor to be informed about all university activities that impact cultural heritage, to obtain expert guidance when needed, and to provide a wide range of information to excavators, students, scientists, and administrators. As the nexus of archeological ethics, the board would perform two primary functions:

First, the ARB would be charged with assisting academic archaeologists and other groups interested in the exploration of UCH in creating archeological projects. In this way, projects would be able to use the combined resources and knowledge base of the board's membership in creating educational and research opportunities for faculty and students alike. This function of the board would not be in any way intended to be a stumbling block for new or existing projects, and its actual operations and procedures would need to be worked out carefully in order to avoid a situation where campus archaeologists would create additional obstacles and red tape for themselves without effectively increasing oversight in the areas where it was needed. ${ }^{17}$ Operational details aside, there are clear ethical principles and professional standards that an ARB would endeavor to uphold, wherever possible, by providing helpful advice and by promoting knowledge of good archaeological practices through a variety of positive and collegial initiatives. The goal of this body would be to offer guidance and to ensure that all universitybased archaeological projects would be models of academic, ethical, and scientific practice.

\footnotetext{
${ }^{17}$ The authors of this paper are well aware that forming this sort of regulatory body will involve a number of institutional and ethical decisions that will be institution specific. These considerations, though vitally important to the success of individual ARBs, fall outside the scope of this paper.
} 
Second, the ARB's members would evaluate external archaeological projects prior to approving these courses for student participation and before accepting those courses for transfer credit or other research activity toward an undergraduate or graduate degree at the ARB's home institution. This final role is one that archaeology faculty members perform routinely already. However, unless there was a committee already performing many of the functions outlined above, this process would be idiosyncratic and performed only on an ad hoc basis at the request of particular students. An important duty of the ARB would be to make field program evaluation more consistent, and to endow the process with institutional recognition and approval.

An ARB at any campus would be explicitly charged with making sure that university based projects and credits are set up from within the framework of applicable laws and conventions for best practices, and board members would need to have no financial or partnership stake in any project brought up for review. In this way, the members would have the professional credentials to speak on these matters, the ethical backing to approve or deny projects that have an impact on the protection of cultural heritage, and the academic authority to speak on behalf of their home institution.

As our administrators and colleagues have already shown that they take potential risks to cultural heritage seriously, we are confident that the ARB will become a reality at URI in the near future. By working to create strong internal research collaborations and by screening external projects for URI student participation, the ARB will allow URI to be certain that its flagship field expeditions and its students are promoting the highest standards of archaeology, both on land and underwater. 
Currently, the URI Archaeology Group is in the process of proposing the ARB to the University and is using members of URI's faculty and administration (including members of other oversight bodies at URI) to work out the many issues needed to bring our ARB from concept to reality. Our broader hope is that our experience in interdisciplinary cooperation will create a positive precedent, and a model for other university based archaeologists.

\section{Acknowledgements}

The authors would like to acknowledge a number of people and groups for their input into this document. We would like to thank the members of the URI archaeology group for their ideas on improving this paper, and for their ongoing commitment to addressing issues of archaeological ethics at an institutional level. In addition, we thank URI's Hazen White Center for Ethics and Public Policy for their financial support, for their comments on a series of presentations of our material in preparation for this publication, and for their helpful advice on where to 'house' an ARB at the University of Rhode Island. Also, we would like to thank the College of Arts and Sciences, the URI Center for Humanities, and the URI Honors Program for their ongoing support. The background issues that led the authors to propose the need for an ARB were presented at a roundtable discussion on underwater archaeology at the American Institute of Archaeology (AIA) in 2008, and issues surrounding the implementation of an ARB were discussed at the 2010 meeting. We would like to thank our fellow creators and signers of the Penn-Brock Statement on UCH for their insights during the workshop where we presented the penultimate version of this article. We would like to single out co-participants in this workshop, Ole Varmer and Jim Delgado, whose insightful comments helped us clarify our position on the need for an ARB, leading us to submit our plan for publication. Finally, we would like to thank the editor and reviewers at JMA for pointing out a number of errors and confusions in early versions of this work. Their insights and edits were instrumental in bringing this piece to its current form. 


\section{References}

Ballard, R. 2008. “Introduction.” In Ballard R (ed.), Archaeological Oceanography, Princeton University Press, Princeton, pp. x.

Carducci, Guido. 2006. "Current Status and Future Prospects for the 2001 Convention: The UNESCO Perspective," The UNESCO Convention for the Protection of the Underwater Cultural Heritage: Proceedings of the Burlington House Seminar October 2005. The Nautical Archeology Society, Fort Cumberland, pp. 1-2.

Ford. B., Borgens, A., and Hitchcock, P. 2010. “Mardi Gras' Shipwreck: Results of a DeepWater Excavation, Gulf of Mexico, U.S.A.," International Journal of Nautical Archaeology 39.1, pp. 76-98.

Foley, B. "Impact of Fishing on Shipwrecks," Woods Hole Institute. http://www.whoi.edu/sbl/liteSite.do?litesiteid=2740\&articleId=4965 (accessed June 1, 2011).

Greene, L., Leidwanger, J., Leventhal, R. and Daniels, B., 2010. “Toward Best Practice in Mediterranean Underwater Archaeology: a report of a recent international workshop and conference on the implications and implementation of the UNESCO Annex in international context," in International Journal of Nautical Archaeology 39.2, pp. 437-439.

Krieger, W. 2006. Can There Be a Philosophy of Archaeology? Lexington Books, Lanham.

Krieger, W. 2011. "Removing the 'Grand 'from Grand Unified Theories,”' Krieger, W. (ed.), Science at the Frontiers, Lexington Books, Lanham, pp. 73-88.

O'Keefe, P. J. 1999, "International Waters," in S. Dromgoogle (ed.), Legal Protection of the Underwater Cultural Heritage: National and International Perspectives. Kluwer Law International, London. 
Painter-Morland, M., 2008, "Systemic Leadership and the Emergence of Ethical

Responsiveness," in Journal of Business Ethics 82, pp. 509.

Søreide, F. 2011, Ships from the Depths: Deepwater Archaeology, Texas A\&M University Press, College Station.

Varmer, O., Gray, J., and Alberg, D. 2010. 'United States: Responses to the 2001 UNESCO

Convention on the Protection of the Underwater Cultural Heritage," Journal of Maritime Archaeology 5, pp.129-141.

Wachsmann, S. (2011) "Deep Submergence Archaeology," in A. Catsambis, B. Ford, and D. Hamilton (eds.) The Oxford Handbook of Maritime Archaeology, Oxford University Press, New York, pp. 202-231.

\section{Bibliography}

Buxton, B. 2011. 'Lost Science, Deepwater Shipwrecks, and the Wheelbarrow of Archimedes," Krieger, W. (ed.), Science at the Frontiers, Lexington Books, Lanham, pp. 51-72.

Dromgoole, S. (ed.) 2006. The protection of the underwater cultural heritage: National Perspectives in Light of the UNESCO Convention 2001. Martinus Nijhoff Publishers, Leiden.

Gould, R. (ed.), 1983. Shipwreck Anthropology, University of New Mexico Press, Albuquerque.

Muckelroy, K. 1978. Maritime Archaeology, Cambridge University Press, Cambridge.

Skinner, B. 1948. Walden Two. Hackett Publishing Company, Indianapolis.

Skinner, B. 1985. “News from Nowhere, 1984,” in The Behavior Analyst, 8: 1, pp. 5-14.

International Council on Monuments and Sites (ed.s) 2006. Underwater cultural heritage at risk: managing natural and human impacts. 